\title{
Revolusi Industri 4.0: Googelisasi Industri Pariwisata dan Industri Kreatif
}

\author{
Poerwanto $^{1}$, Yoedo Shambodo ${ }^{2}$ \\ poerwantoku@gmail.com,yoedo.shambodo@uai.ac.id
}

\begin{abstract}
Today's technology revolution engages the 4th wave which is called 4.0 industrial revolution. This 4.0 industry refers to technology that produce to digital technology. Entrepreneurship world has experienced a great transformation which has turned from conventional technology into the digital one. Google has created various of apps those are constructing the communicating ecosystem. The google-based technology facilatates the production process.

It is really challenges and opportunity for Indonesian tourism industry and creative industry.

Keyword: industry 4.0, googlization, tourism industry, creative industry
\end{abstract}

\begin{abstract}
Abstrak
Revolusi teknologi kini memasuki gelombang keempat yang disebut dengan revolusi industri 4.0. Industri 4.0 merupakan revolusi teknologi yang melahirkan teknologi digital. Dunia usaha mengalami transformasi besar di mana sebagian besar proses produksi beralih dari teknologi konvensional ke teknologi digital. Google telah menciptakan berbagai aplikasi layanan yang membangun ekosistem dalam berinteraksi. Produk-produk berteknologi tinggi google memfasilitasi proses produksi-googelisasi. Googelisasi merupakan tantangan dan peluang bagi industri pariwisata dan industri kreatif Indonesia.
\end{abstract}

Kata Kunci: industri 4.0, googelisasi, industri pariwisata, industri kreatif

\footnotetext{
${ }^{1}$ Penulis dan pembelajar Pariwisata

${ }^{2}$ Dosen Program Studi Ilmu Komunikasi FISIP Universitas Al Azhar Indonesia dan praktisi periklanan
} 


\section{Pendahuluan}

Revolusi industri telah berada pada gelombang keempat, yang dikenal sebagai revolusi industri 4.0. Revolusi 4.0 yang menghasilkan teknologi digital telah mendasari koneksi data dalam skala besar, luas serta berlangsung dengan super cepat yang kejadiannya tidak pernah kita bayangkan. Revolusi industri 4.0 merupakan tren proses produksi yang berbasis teknologi digital yang menciptakan perubahan pada semua sektor kehidupandan melahirkan teknik-teknik produksi terkini, yang mampu meningkatkan produktivitas serta efisiensi secara berkelanjutan.

Revolusi industri 4.0 merupakan kelanjutan dari revolusi industri sebelumnya, mulai dari revolusi pertamayang menemukan mesin uap dan kereta api (1750-1830), kemudian kedua, penemuan listrik, alat komunikasi, kimia dan minyak (18701900), dan ketiga, penemuan komputer, internet, dan telepon genggam smpai pada teknologi digital dan informasi (1970 - an hingga sekarang).

Industri 4.0 adalah teknologi digital yang melahirkan teknologiteknologi cerdas diantaranya; kecerdasan buatan (artificial intellegence), mahadata (bigdata), robot, teknologi finansial, perdagangan elektronik (e-commerce), pemasaran elektronik (e-marketing). Hampir semua kegiatan industri baik di sektor manufaktur maupun jasa kini menggunakan teknologi digital.

Teknologi digital menciptakan perubahan secara terus-menerus dan menjadi gangguan dalam proses produksi, dantatanan kehidupan sosialekonomi-budaya. Teknologi digital meningkatkan produktivitas, efisiensi, dan efektivitas. Teknologi digital memungkinkan proses produksi dilakukan secara komprehensif dari mulai perencanaan, produksi, pemasaran dan layanan purna jual.

Industri 4.0 telah membuat semua aktivitas kehidupan di semua sektor menjadi sahih, dan semua pihak harus bisa menerima. Di sisi lain, kecanggihan teknologi digital dalam proses produksi, menyebabkan pengurangan aktivitas manusia dalam berbagai hal termasuk proses produksi. Penggunaan mesin-mesin otomatisrobot-robot dari mulai perencanaan, produksi sampai pada pemasaran elektronik-online memperpendek jarak antara produsen dengan target pasarnya. Efek yang cukup sangat terasa berkurangnya penggunaan tenaga kerja manusia.

Dampaknya, upaya penyerapan tenaga kerja dalam proses pembangunan nasional mengalami hambatan. Penciptaan dan penyerapan tenaga kerja manusia dilakukan hanya bagi sebagian masyarakat dari mereka yang memiliki kualifikasi tertentu saja - teknologi modern.

Teknologi telah mendominasi kehidupan manusia sekarang dan masa depan. Teknologi telah dipahami dari berbagai pendekatan. Menurut Boone dan Kurzt (200) teknologi diartikan sebuah aplikasi dari pengetahuan yang didasarkan atas berbagai penemuan dan inovasi ilmu pengatahuan. Dari aspek sosial Perrow (1967, dalam Robbins,1990) teknologi dikatakan sebagai tindakan yang dilakukan seorang individu terhadap sebuah objek, dengan atau tanpa bantuan alat atau perlengkapan mekanis, untuk membuat perubahan tertentu pada objek tersebut.

Dalam proses operasi organisasi baik nirlaba mau pun profit, teknologi dipahami sebagai pengetahuan, peralatan dan atau teknik yang digunakan untuk mengubah masukan 
menjadi luaran. Teknologi menggerakkan perekonomian. Dalam perkembangannya, teknologi secara nyata mampu memberi kesempatan atau peluang baru sangat besar dan dinamis bagi mereka yang memahami dan menguasai teknologi komunikasi informasi. Namun, di sisi lain, teknologi mengurangi pekerjaan yang tersedia yang berarti pengurangan tenaga kerja.

Namun bagaimanapun, manusia tetaplah menjadi komponen terpenting dalam pengembangan sumber daya. Teknologi menggerakkan manusia melakukan perubahan berkelanjutan yang mendorong manusia untuk berkarya-manusia bersumber daya. Manusia bersumber daya, oleh Drucker (1985, dalam Classic Drucker:2006) disebut sebagai knowledge worker, adalah penggerak organisasi dan mereka adalah yang menciptakan peluang-peluang baru secara terus menerus. Lebih lanjut Drucker mengatakan bahwa dalam organisasi berbasis pengetahuan, produktivitas pekerja individulah yang membuat seluruh sistem berhasil. Dalam tenaga kerja tradisional, pekerja melayani sistem; dalam tenaga kerja berpengetahuan, sistem harus melayani pekerja.

Sektor jasa merupakan salah satu sektor perekonomian yang berbasis pada kemampuan sumberdaya manusia, yang kini menjadi pilihan dalam proses pembangunan saat mana industri manufaktur sedang mengalami kemandegan. Proses produksi sektor jasa dimotori oleh manusia yang memiliki kecerdasan, keahlian, kemampuan berkomunikasi, memiliki komitmen, dan konsisten terhadap komitmennya-manusia bersumber daya. Manusia bersumber daya adalah modal manusia (human capital).

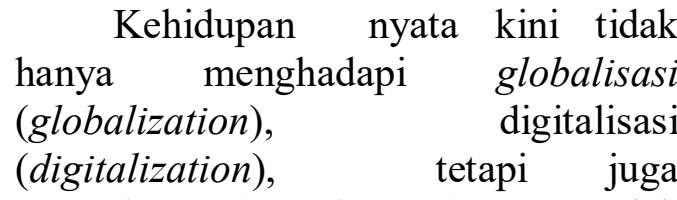
googelisasi (googlization) yang telah mengubah pola komunikasi masyarakat dalam berinteraksi. Kebutuhan akan informasi dan atau data tentang apa pun bisa diperoleh dengan mudah dan cepat melalui sebuah mesin pencari (search engine) bernama google. Dampaknya, proses produksi baik pada industri manufaktur mau pun jasa, serta alur informasi mengalami perubahan secara cepat dan berkelanjutan.

Setiap organisasi yang bergerak di bidang apa pun harus mampu meningkatkan kapabilitasnya dengan melakukan transformasi melalui manusia bersumber daya.

\section{Manusia Bersumber Daya}

Dunia usaha berada pada era kompetisi tinggi yang difasilatasi mesin serba bisa yang bernama google. Perusahaan-perusahaan terkemuka masuk ke seluruh penjuru dunia, mencari lokasi yang mungkin menguntungkan dengan memindahkan proses produksinya dengan model bisnis alih daya (outsourcing)globalisasi. Mereka membidik negaranegara yang memiliki sumberdaya alam untuk dieksploitasi, serta sumberdaya manusia yang masih bisa dibayar dengan murah. Tujuan utamanya adalah efisiensi-low-cost production untuk memperoleh hasil yang besar.

Globalisasi menurut Poerwanto (2018) dipahami sebagai fenomena kehidupan di mana kepentingan individu-individu, kelompok dan bahkan negara-bangsa berada di bawah kepentingan dunia secara menyeluruh. Sedangkan Ohmae (1991) mendeskripsikan fenomena globalisasi sebagai "dunia tanpa batas" di mana 
peta politik, batas-batas antarnegara sama jelas dengan sebelumnya. Akan tetapi pada peta kompetitif, peta memperlihatkan arus riil kegiatan keuangan dan industri, batas-batas itu sebagian besar sudah hilang. Dari semua kegiatan yang menghapuskan batas-batas tersebut, barangkali yang paling gigih adalah arus informasi.

Masyarakat dunia kini telah menjadi masyarakat yang terhubungkan. Dunia usaha menjadi terjalin dalam membangun meningkatkan efisiensi dan produktivitas. Teknologi komunikasi informasi adalah kenyataan yang harus dihadapi dalam persaingan di era dunia tanpa batas. Semua negara dan perusahaan perlu memiliki daya saing untuk memperoleh posisi terbaik.

Daya saing menurut Zuhal (2010) adalah gambaran bagaimana suatu negara termasuk perusahaanperusahaan dan SDM-nya mengendalikan kekuatan kompetensi yang dimilikinya secara terpadu guna mencapai kesejahteraan dan keuntungan. Selanjutnya Zuhal menjelaskan bahwa dalam porsi yang besar, kekuatan daya saing suatu bangsa ditentukan oleh kemampuan perusahaan-perusahaan dan SDM-nya dalam menghasilkan nilai tambah setinggi mungkin. Sedangkan peran negara lebih ditujukan untuk menunjang dan memfasilitasi kerangka kerja yang dapat memaksimalkan nilai tambah ekonomi.

Intinya dari pemikiran Zuhal adalah bahwa daya saing memerlukan SDM-iptek yaitu SDM-SDM dengan kekuatan knowledge, kreativitas, dan kemampuan inovatif yang memadai untuk membangun sistem ekonomi berbasis pengetahuan knowledge-based economy (KBE).

Dapat diartikan bahwa kemampuan daya saing terletak pada sumberdaya manusia berpengetahuan dalam proses produksi. Drucker (1991 dalam Classic Drucker:2006) menjelaskan tantangan utama terbesar yang dihadapi oleh manajer negara maju di dunia adalah meningkatnya produktivitas pekerja berpengetahuan (knowledge worker) dan pekerja jasa (service worker). Tantangan ini, yang akan mendominasi agenda manajemen dalam beberapa dekade ke depan, pada akhirnya akan menentukan kinerja kompetitif perusahaan. Artinya, pekerja berpengetahuan dan pekerja jasa merupakan modal bagi perusahaan. Mereka adalah aset potensial yang dapat melakukan perubahan atau mengendalikan perubahan lingkungan organisasi.

Era teknologi digital adalah modal intelektual bagi organisasi. Stewart (1997) mendefinisikan modal intelektual (Intellectual Capital) sebagai: materi intelektual yaitu pengetahuan, informasi, kekayaan intelektual, pengalaman yang digunakan untuk menciptakan kesejahteraan. Lebih lanjut Stewart menambahkan bahwa pengetahuan telah menjadi faktor produksi yang penting dan oleh karena itu aset intelektual harus dikelola oleh perusahaan.

Dalam kaitan dengan organisasi Poerwanto (2018) menjelaskan bahwa modal intelektual adalah pengetahuan, keterampilan dan komitmen yang dimiliki oleh sumber daya manusia sebagai basis operasional kegiatanmerupakan karyawan berbasis pengetahuan (knowledge-based worker). Harrison dan Sullivan (2000) menjelaskan bahwa keberhasilan perusahaan sangat dipengaruhi oleh usaha-usaha rutin perusahaan untuk memaksimalkan nilai-nilai dari modal intelektual yang dimiliki perusahaan. Sedangkan Drucker (2002, dalam 
Classic Drucker: 2006) mengatakan bahwa knowledge worker adalah minoritas dari total tenaga kerja. Tetapi mereka telah menjadi pencipta utama dari kesejahteraan dan pekerjaan. Kesuksesan (sesungguhnya, perjuangan) setiap bisnis akan semakin bergantung pada kinerja knowledge worker. Namun, dalam organisasi berbasis pengetahuan, produktivitas individulah yang membuat seluruh sistem berhasil. Dalam tenaga kerja tradisional, pekerja melayani sistem; dalam tenaga kerja berpengetahuan, sistem harus melayani pekerja.

Organisasi pada masa sekarang perlu menyiapkan strategi pengelolaan dan pengembangan sumber daya manusia yang berbasis pada tuntutan perubahan berkelanjutan, kompetisi, dan kompetensi. Kehidupan organisasi modern era "googelisasi" tidak lagi sekedar beradaptasi dengan lingkungannya, tetapi dituntut untuk belajar secara berkesinambungan untuk membangun keunggulan dan daya saing, melalui transformasi dan pemberdayaan manusia bersumber daya.

Globalisasi dan digitalisasitelah melahirkan teknologi-teknologi baru yang pada tataran berikutnya melahirkan searching engine dan aplikasi-aplikasi terbarukan yang sementara ini ada yang mengistilahkan sebagai googelisasi (googlization) yangmenjadi salah satu aset penting dalam operasi-operasi organisasi.

Manusia bersumber daya yang diperlukan organisasi pada era globalisasi di mana persaingan menjadi pertempuran yang tiada henti, adalah manusia yangmemiliki kompetensi, komitmen, konsisten dan kohesi dalam pengelolaan tujuan-tujuan organisasi.

Revolusi industri 4.0 telah merubah gaya hidup masyarakat. Seperti kita ketahui bahwa kini sektor industri manufaktur kini mengalami pelambatan karena tingkat pembelian barang kebutuhan menurun. Gaya hidup masyarakat berubah dari belanja barang ke belanja jasa, seperti kuliner, perjalanan dan atau ibadah (umrah).

Industri pariwisata telah menjadi sektor pendorong pertumbuhan sektorsektor perekonomian lain salah satunya industri kreatif.

\section{Linimasa Revolusi Industri}

Lim, (2019) mengatakan linimasa industri dimulai dari awal abad 19 sebagai industri 1.0 yang ditandai dengan penemuan mesin uap, kapal dan pesawat, perdagangan serta pariwisata lintas antar benua. Sedangkan Thangaraj, dan Narayanan, (2018) mengatakan bahwa industri 1.0 memunculkan manufaktur dengan kapabilitas produksi besar, pengembangan bisnis pribadi menjadi organisasi yang terdiri dari pemilik, manager, dan karyawan yang melayani pelanggan.

Menurut Lim, (2019) Industri 2.0 berawal dari inovasi listrik dan teknologi elektronik, manufaktur berdaya elektronik, inovasi komputer dan personal komputer komersial. Robot, mesin mekanis dan otomatis menggantikan kerja manusia untuk produksi massa dalam industri. Dan, Thangaraj, dan Narayanan (2018) industri 2.0 juga berkenaan dengan pengembangan program manajemen dan pembagian kerja buruh untuk meningkatkan efektivitas dan efisiensi fasilitas manufaktur.

Thangaraj, dan Narayanan, (2018) menambahkan, inovasi mesin otomatis individual untuk menggantikan kerja operator, software dan hardware dalam integrase sistem produksi pabrik, dan perluasan operasi perakitan di negara - negara berbiaya rendah untuk manajemen rantai suplai 
pada dekade akhir abad 20 menjadi penanda revolusi industri 3.0. Selain itu, menurut Lim (2019) industri 3.0 adalah era berkembangnya cyberspace, globalisasi teknologi komunikasi informasi, teknologi transportasi yang lebih cepat, serta inovasi dan perkembangan internet sebagai basis pengetahuan kolektif universal berdasarkan algoritma.

Lim (2019) mengatakan bvahwa awal abad 21 sebagai era industri 4.0 dikarakteristikkan dengan perkembangan artificial intelligence (AI), manufaktur aditif, robot dan kendaraan otomatis, mesin yang dikontrol algoritma, softwarel aplikasi yang mampu memprediksi perilaku berbasis algoritma, dan revolusi media sosial. Thangaraj, dan Narayanan (2018) mengatakan industri berkoneksi dengan IoT (internet of things) yang memungkinkan teknik manufaktur untuk berbagi informasi, menganalisis dan memandu aksi cerdas dalam bentuk robot, AI, teknologi kognitif, dan augmented reality.

\section{Industri 4.0}

Istilah industri 4.0 pertama kali muncul saat Hannover Fair sebagai suatu strategi industri Jerman dan akhirnya pada April 2013 sebagai laporan akhir Hannover Fair dicetuskan definisi industri 4.0 sebagai personalisasi (customization) produk dalam kondisi fleksibilitas, otomatisasi, dan produksi massal yang membutuhkan metode dan sistem yang bisa berorganisasi sendiri untuk membentuk hubungan manusia dan mesin dengan dunia virtual. Konsep indutri 4.0 menurt Devezas, Leitao, dan Sarygulov, (2017) dikenalkan kepada publik global dalam World Economic Forum di Davos, Swiss pada 2015 melalui buku The Forth Industrial Revolution oleh Klaus Schwab. Apa definisi industri 4.0? Terdapat beberapa definisi industri 4.0, antara lain :

- Shukodolov dalam Popkova, Ragulina, Bogovis, (2019) mendefinisikan 4.0 sebagai metode revolusioner dalam organisasi produksi industri berbasis pada digitalisasi dan otomatisasi proses industri yang menghapuskan keterbatasan objek fisik dan mengubahnya menjadi sistem kompleks dan komprehensif dari elemen - elamen produksi yang saling terkoneksi dan saling bergantung.

- Gunal, Karatas dalam Gunal, (2019) industri yang memanfaatkan perkembangan teknologi digital dan simulasi dalam manufaktur untuk produk yang lebih baik, lebih banyak, dan biaya lebih rendah.

- Dornberger, Inglese, Korkut, Zhong dalam Dornberger, (2018), industri yang semua mesin produksinya dan jasa pendukung value-nya berkoneksi dengan internet. 


\section{REVOLUSI INDUSTRI 4.0}

1st revolution
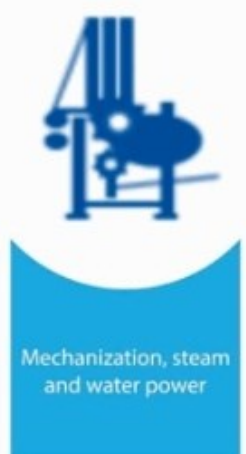

Desain oleh: Yoedo Shambodo

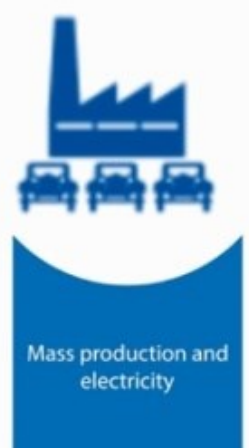

\section{Industri pariwisata}

Pariwisata adalah fenomena global yang universal, dan telah menjadi suatu kebutuhan dasar kehidupan manusia untuk memperoleh keseimbangan hidup dan kesejahteraan. UNWTO menengarai bahwa pembangunan pariwisata melibatkan ratusan juta manusia baik sebagai wisatawan, pelaku-pelaku bisnis pariwisata, lembaga pendidikan, tenaga profesional serta masyarakat secara luas, yang berdampak pada pertumbuhan perekonomian dunia.

Potensi daya tarik wisata, kini telah dikembangkan untuk menjadi motor penggerak pertumbuhan ekonomi secara besar-besaran. Pilihan tersebut didasarkan pada kenyataan bahwa pariwisata adalah industri yang unik, yaitu wisatawan mendatangi produk-atraksi, sulit dibatasi oleh berbagai kepentingan seperti kondisi alam-sosial-budaya yang bagaimanapun, mendatangkan devisa serta membuka kesempatan kerja dan usaha baru secara simultan, serta kreativitas. UNWTO (United Nations World Tourism Organization) memperkirakan pada tahun 2020 tercatat kurang lebih 1,6 miliar wisatawan mengunjungi berbagai objek wisata di seluruh penjuru dunia,

\author{
3rd revolution \\ 4th revolution
}
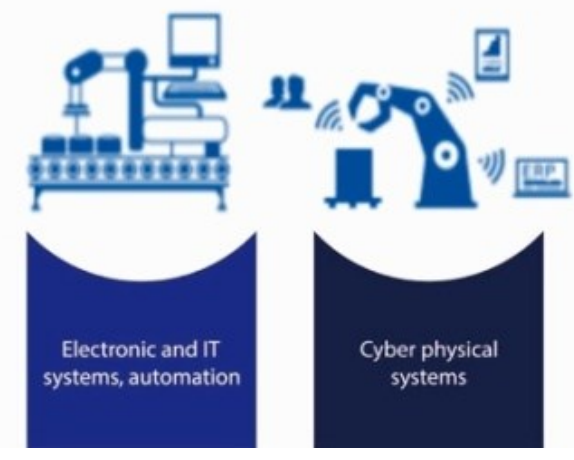

dengan pengeluaran sekitar 2000 miliar US\$, dan menciptakan sekitar 193 juta kesempatan usaha dan kerja.

Indonesia adalah negara yang memiliki daya tarik wisata beragamalam, sosial, budaya merupakan keunggulan kompetitif yang jika dikembangkan secara profesional serta dapat memperkuat daya saing negara bersangkutan.

Pariwisata telah menjadi salah satu agen perubahan yang menciptakan peluang-peluang dan tantangan-tantangan baru yang mendorong munculnya ide-ide baru, kreativitas dan pengetahuan. Poerwanto (2017) mendeskripsikan bahwa pariwisata kini telah diproyeksikan menjadi mesin pendorong pertumbuhan di berbagai aspek kehidupan; perekonomian, industri, mobilitas sosial dan industri kreatif. Pariwisata telah menjadi tumpuan dalam pembangunan perekonomian dan peningkatan kesejahteraan sosial khususnya masyarakat lokal di mana atraksi wisata berada dengan menyediakan lapangan kerja dan usaha baru.

Informasi menunjukkan bahwa pada tahun 2017 industri pariwisata Indonesia tumbuh 22 persen jauh lebih tinggi di atas pertumbuhan industri 
pariwisata ASEAN sebesar 7 persen, dan pertumbuhan pariwisata dunia 6,4 persen. Catatan The World Travel and Tourism Council pariwisata Indonesia kini berada di urutan ke-9. Informasi tersebut menjadi tantangan bagi industri pariwisata Indonesia. Kini, industri pariwisata menghadapi perubahan perilaku wisatawan yang disebabkan oleh tren pergeseran kependudukan.

Travel Tech Consulting Yang disitir majalah SWA 24 juli - 7 Agustus 2019 mengatakan bahwa traveller millenial akan mendorong pariwisata 4.0. 70 persen traveller melakukan searching dan sharing melalui internet (digital) dan 51 persen dari traveller asing adalah milenial. Sedangkan, Ari Prasetyo Kepala Bidang Perencanaan Strategis Kementrian Pariwisata, dalam Harian Kompas 25-9-2019 mengemukakan, sekitar 70 persen wisatawan merencanakan perjalanan secara digital, mulai dari mencari destinasi, memesan, bertransaksi, hingga mengunggah pengalaman berwisata ke media sosial. Bahkan, lebih dari 200 ulasan pengalaman wisata diunggah di TripAdvisor per menit nya (cnnindonesia, 2019).

Kini, di era googelisasi, model pengembangan pariwisata harus bisa meneropong jauh ke depan karena setelah generasi $\mathrm{Y}$ akan muncul generasi $\mathbf{Z}$ yaitu generasi yang lahir setelah tahun 2000, generasi yang tumbuh di era digital yang selalu ingin terkoneksi dimanapun dan kapanpun. Mereka adalah segmen pasar yang penting, bukan hanya karena besar dan terus tumbuh, namun kemampuan mereka dalam meng-influence cukup masif.

\section{Industri kreatif}

Industri kreatrif dipahami sebagai industri yang berbasis pada keterampilan individu yang bisa berasal dari bakat atau pelatihan jangka panjang. Departemen Perdagangan Republik Indonesia tahun (2007) mendefinisikan industri kreatif sebagai: Industri yang berasal dari pemanfaatan kreativitas, keterampilan serta bakat individu untuk menciptakan kesejahteraan serta lapangan pekerjaan melalui penciptaan dan pemanfaatan daya kreasi dan daya cipta individu tersebut. Industri kreatif merupakan bagian integral dari ekonomi kreatif.

Amabile (1997) mendefinisikan kreativitas sebagai penciptaan ide-ide baru yang bisa mengakomodasi kebutuhan-kebutuhan atau menangkap peluang-peluang baru. Kreativitas merupakan langkah pertama dalam inovasi, yang sangat penting bagi keberhasilan jangka panjang. Kreativitas juga bisa dirangsang dalam organisasi. Perusahaan-perusahaan atau departemen-departeman di dalam perusahaan dapat dibuat menjadi kreatif dan memprakarsai perubahan.

Teknologi digital telah mendorong konsentrasi industri dan perekonomian berpindah dari negaranegara maju khususnya barat ke negara-negara berkembang seperti India, ASEAN serta Amerika Latin yang mendorong kreativitas di berbagai sektor. Kini, di samping pariwisata, industri kreatif menjadi salah satu pilihan pembangunan. Departemen Perdagangan RI (2008) menjelaskan bahwa ekonomi kreatif adalah wujud dari upaya mencari pembangunan yang berkelanjutan melalui kreativitas, yang mana pembangunan berkelanjutan adalah suatu iklim perekonomian yang berdaya saing dan memiliki cadangan 
sumber daya terbarukan. Pesan besar yang ditawarkan ekonomi kreatif adalah pemanfaatan cadangan sumber daya yang bukan hanya terbarukan, bahkan tak terbatas, yaitu ide, talenta dan kreativitas.

Pengembangan industri kreatif diarahkan untuk lebih menitikberatkan pada industri berbasis: (1) lapangan usaha kreatif dan budaya (creative cultural industry); (2) lapangan usaha kreatif (creative industry), atau (3) Hak Kekayaan Intelektual seperti hak cipta (copyright industry). Kerajinan batik, tenun, bordir dan ukiran, kerajinan cinderamata khas masingmasing daerah, fesyen (fashion) di Indonesia merupakan bagian dari industri berbasis kreativitas yang mampu mendorong tumbuhnya industri-industri ikutan lain yang berkaitan.

Walravens, dalam Nijs dan Peters (2002) menyatakan bahwa kreativitas dalam proses pembangunan menunjuk pada 'menemukan solusi untuk problemproblem di mana yang lain belum pernah menemukan dan mengaplikasikan kombinasi pengetahuan untuk diterapkan pada area problem baru'. Sedangkan Binkhorst (2007) memahami kreativitas adalah diasosiasikan dengan 'mengerjakan sesuatu secara manual' atau dengan 'menciptaan sesuatu' seperti melukis, membuat musik, membuat kerajinan dan lainnya.

Kreativitas berasal dari individu yang menjadi karyawan atau mitra organisasi. Temuan Poerwanto dan Zakaria Lantang (2012) mengatakan bahwa industri kreatif berbasis seni batik pesisiran ditopang oleh lima aktor utama, yaitu; pebisnis, pembatik atau pekerja batik, pemerintah, selera pasar dan intelektual. Hal tersebut menunjukkan bahwa individu berketrampilan adalah salah satu elemen mitra pemangku kepentingan industri kreatif.

Produk industri kreatif merupakan bagian dari industri pariwisata. Produk industri kreatif berbasis kerajinan dan budaya menjadi cinderamata bagi para pelancong sebagai kenangan. Di Indonesia sektor industri kreatif dan pariwisata terus bertumbuh dan berkembang secara signifikan beriringan, sekalipun sektor pariwisata beberapa target capian dari pemerintah tidak semua dapat dicapai, misal target kunjungan wisatawan manca negara, di mana tahun 2018 target kunjungan wisatawan mancanegara hanya 15,8 juta dari target 17 juta. Namun demikian, sektor pariwisata Indonesia tumbuh diatas 20 persen jauh di atas pertumbuhan industri pariwisata dunia yang hanya 6,4 persen. Kondisi pertumbuhan tersebut menjadi tantangan baru bagi industri pariwisata Indonesia.

Dari berbagai informasi dapat diketahui bahwa industri kreatif dan industri pariwisata kini cenderung dimotori oleh generasi melineal. Poerwanto (2018) mengatakan, generasi melineal adalah generasi yang lahir 1990-an dan akan berlanjut dengan generasi $\mathrm{Z}$ yang lebih manja yang dibesarkan oleh kemajuan teknologi komunikasi dan yang memiliki kemauan berpikir maju.

Departemen Perdagangan RI, 2007 mengidentifikasi 14 subsektor yang merupakan industri berbasis kreativitas adalah: Periklanan; Arsitektut; Pasar Barang Seni; Kerajinan; Desain; Fesyen; Video, Film dan Fotografi; Musik; Seni pertunjukkan; Penerbitan dan Percetakan; Layanan Komputer dan Piranti Lunak; Televisi dan Radio; Riset dan Pengembangan. Dari ke 
empat belas subsektor tersebut pasar barang seni, kerajinan (cinderamata khas kedaerahan), desain, fesyen, dan seni pertunjukan merupakan subsektor yang mempunyai kontribusi terhadap industri pariwisata. Konsekuensinya, adalah bagaimana pemangku kepentingan merajutnya ke dalam ekosistem bisnis yang berkelanjutan.

Kini, industri kreatif memiliki tantangan teknologi. Kecerdasan buatan (artificial intellegence, AI) telah menjadi pilihan dalam melakukan efisiensi, ketepatan dan kecermatan dalam berinovasi, yang menjadi ancaman bagi industri kreatif kerajinan berbasis keterampilan individu.

\section{Kesimpulan}

Karim Temsamani, President Google Asia-Pasific, pada pembukaan program 'Growing with Google' 12 April 2018 di Singapura mengatakan "Teknologi digital tidak hanya mampu menciptakan produk, namun juga ekosistem serta keterhubungan antara konsumen, partner (seperti Publisher dan developer), serta pengiklan. (Majalah MIX April-Mei 2018)

Google memiliki produk layanan berteknologi tinggi yang mampu membangun ekosistem pada semua tingkatan bisnis - besar-menengahkecil. Produk layanan google seperti Search, Maps Android, Play, YouTube, Chrome dan Gmail, kini digunakan oleh semua kalangan termasuk UMKM. Karim juga menjelaskan ketujuh produk layanan tersebut bukan hanya aplikasi, tetapi juga platforms. Dengan platforms, inovasi bisa datang dari mana saja dan siapa saja menciptakan produk populer.

Sebagian dari pelaku industri kreatif merupakan UMKM yang banyak menyerap tenaga kerja terampil. Teknologi digital membantu UMKM berinovasi, berkreasi dan menjalin hubungan dengan pemangku kepentingan untuk pertumbuhan.

Gaya hidup wisatawan dalam mencari informasi destinasi, memperbandingkan antar produk, termasuk informasi tentang atraksi wisata, produk-produk yang memiliki khas dari destinasi yang dikunjungi seperti cinderamata, kuliner atau produk-produk kreatif khas lainnya dan berbagi informasi kini telah mereka lakukan secara digital. Singkatnya mereka search and share menggunakan media digital. Ada tiga ciri digital lifestyle yaitu: mobile, personal, dan interactive (Pariwisata, 2019)

Industri pariwisata dan Industri kreatif 4.0 merupakan industri yang harus memanfaatkan teknologi digital. Setiap bisnis pariwisata dan industri kreatif selayaknya menjadi bisnis online dan bersinergi karena keduanya memiliki pelanggan yang hampir sama.

Sinergitas industri pariwisata dan industri kreatif dari hulu sampai ke hilir yang dikerjakan dengan menggunakan produk-produk layanan berteknologi tinggi googlegoogelisasi akan membangun ekosistem perekonomian nasional yang dapat memicu petumbuhan ekonomi yang lebih tinggi. Industri pariwisata dan industri kreatif harus memiliki skenario bisnis yang kuat agar dapat mampu menjadi pelopor pertumbuhan perekonomian nasional.

Pemerintahan periode kedua Presiden Joko Widodo telah menentukan 5 kawasan strategis pariwisata nasional super prioritas, yaitu; Danau Toba, Borobudur, Mandalika, Labuan Bajo dan Manado-Bitung-Likupang.

Googelisasi merupakan kunci 
sukses pelaksanaan program super prioritas tersebut.

Selaras dengan pengembangan industri pariwisata di Indonesia akan diikuti oleh berekembangnya UMKM di bidang kerajinan-kreatif yang memproduk barang cinderamata yang pasti juga diminati oleh para pelancong baik dalam negeri maupun mancanegara. Di Indonesia industri kreatif diperkirakan menyumbang sekitar 15 juta pekerja, dan ekspor lebih dari US\$ 20 miliar. Program super prioritas pariwisata Indonesia akan memberi kesempatan yang besar pada industri kreatif, karena para pelancong juga akan mencari produkproduk kreatif khas daerah di destinasi yang mereka kunjungi.

Google memberi kemudahan pada para pelancong (traveller) untuk mengakses pemilihan dan pemesanan amenitas dan atraksi di manapun, kapanpun dan oleh siapapun. Dalam upaya merealisasikan industri pariwisata dan industri kreatif 4.0, diperlukan kesiapan semua pemangku kepentingan untuk bekerja profesional. Pemerintah harus memfasilitasi dan menjadi motor penggerak mesin pertumbuhan ekonomi nasional dengan meningkatkan profesionalitas sumberdaya manusia. Sudah siapkah sumberdaya manusia Indonesia khususnya di kedua sektor tersebut? Jawabannya, harus siap dan harus disiapkan, karena industri 4.0 adalah roh dan landasan dalam menghadapi revolusi industri lanjutan.

\section{Daftar Pustaka}

Amabile, Teresa M., 1997, Motivating Creativity in Organizations; On Doing What You Love and Loving What You Do, California Management Review 40, No.1

Binkhorst, E. 2005. Creativity in the experience economy, towards the co-creation tourism experience?. Paper presented at the ATLA annual Conference 'Tourism, Creativity and Development'. Barcelona. November

Boone, Louis E., David L. Kurtz. 2000. Contemporary Business 2000, Hardcourt Inc, terjemahan Erlangga. Jakarta. 2002

Devezas, Tessaleno, Joao Leitao, Askar Sarygulov. 2017. Industry 4.0 : Entrepreneurship and Structural Change in the New Digital Landscape. Gewerbestrasse: Springer

Dornberger, Rolf. 2018. Business Information Systems and Technology 4.0 : New Trends in the Age of Digital Change. Gewerbestrasse : Springer

Drucker Peter F. 2006. Classic Drucker. Havard Business School Published. Boston

Gunal, Murat M. 2019. Simulation for Industry 4.0 : Past, Present, and Future. Gewerbestrasse : Springer

Harrison, S., dan Sullivan, P. 2000. Profiting From Intellectual Capital: Learning From Leading Companies. Journal of Intellectual Capital. Vol.1, No.1.

Lim, Tai Wei. 2019. Industrial Revolution 4.0, Tech Giants, and Digitized Societies. Singapore: Palgrave MacMillan

Nijs, D. and Peters, F. 2002. Imagineering. Het creeren van belevingswereldan. Amsterdam. Boom. 


$\begin{array}{lr}\text { Ekonomi Kreatif } & \text { Indonesia } \\ \text { 2025, } & \text { Departemen } \\ \text { Perdagangan } & \text { Republik } \\ \text { Indonesia. } & \end{array}$

Ohmae, Kenichi.1989. The Mind of

Strategist. The Art of Japanese

Business. New York. McGrawHill

Ohmae, Kenichi . 1991. The Borderless World. Harper Business, New Jersey

Poerwanto. 2003. Transformasi Organisasi: Dampaknya Terhadap Peran Sumber Daya Manusia Bidang Pariwisata. Aspirasi: Jurnal Ilmu Soaial dan Ilmu Politik. FISIP. Universitas Jember, Vol.XIII, No. 2., Desember

Poerwanto. 2010. Inovasi Produk dan Motif Seni Batik Pesisiran Sebagai Basis Pengembangan Industri Kreatif dan Kampoeng Wisata Minat Khusus.Laporan Penelitian, DIPA Universitas Jember 2010

Poerwanto, Zakaria.L.S. 2012. Inovasi Produk dan Motif Seni Batik Pesisiran Sebagai Basis Pengembangan Industri Kreatif dan Kampung Wisata Minat Khusus. Jakarta. Jurnal ALAZHAR Indonesia

Poerwanto.2017. Pembangunan Pariwiswata Berbasis Pariwisata: Reonrientasi dari wisata rekreatif ke wisata kreatif. Jember. Journal of Tourism and Creativity. Program Studi D III Usaha Perjalanan Wisata FISIP Univ Jember

Poerwanto.2018. New Business Administration: paradigma baru Pengelolaan Bisnis Dalam Era
Dunia Tanpa Batas. Edisi ke-2. Yogyakarta. Pustaka Pelajar.

Poerwanto dan Reza P Yudha. 2019. Persepsi Generasi Millineal terhadap Jilbab sebagai Indentitas, Fesyen, dan Komunikasi Verbal. Jember. Journal of Tourism and Creativity. Program Studi Diploma III Usaha Perjalanan Wisata, FISIP Universitas Jember

Popkova, Elena G., Yulia V. Ragulina, Aleksei V. Bogoviz. 2019. Industry 4.0: Industrial Revolution of the $21^{\text {st }}$ Century. Gewerbestrasse : Springer

Robbins, Stephen P. 1990. Organization Theory: Structure, Design and Applications, Prentice-Hall, N.J (terjemahan 1994). Penerbit Arcan. Jakarta

Roos, J. Dan Von Krogh. G.1996. The Epistemological Challenge: Managing Knowledge and Intellectual Capital. European Management Journal. Vol 14, Issue 14, August

Stewart, T. 1997. Intellectual Capital: The New Wealth of Organization. New York. Doubleday.

Thangaraj, Jeevitha, Ramya Lakshmi Narayanan. Industry 1.0 to 4.0: The Evolution of Smart Factories. October 2018. Research Gate. https://www.researchgate.net/pu blication $/ 330336790$ diakses pada 8 Desember 201911.47 p.m.

Zuhal. 2010. Knowledge and Innovation: Platform Kekuatan Daya Saing. Jakarta. PT Gramedia Pustaka Utama 
Majalah MIX Marketing \& Coomunication. April - Mei 2018

Kompas.com. Akhirnya, Hadir Jejaring Sosial untuk "Traveler" (internet). 5 Mei 2013, 15:37WIB.https://travel.kompas. $\mathrm{com} / \mathrm{read} / 2013 / 05 / 05 / 1537437 /$ Akhirnya..Hadir.Jejaring. Sosial. untuk. Traveler?page=all. (Diaks es pada16 Desember 2019)

Kemenpar.CEO Message \#11 Go Digital The more digital, the more personal. The more digital, the more professio (internet), 30 November 2018. Tersedia darihttps://www.kemenpar.go.id/ post/ceo-message-11-go-digitalthe-more-digital-the-morepersonal-the-more-digital-themore-professio (diakses 16 Desember 2019). 
